\title{
Генерация поверхностных плазмон-поляритонов в углеродной нанотрубке с токовой накачкой
}

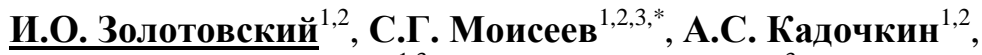 \\ Ю.С. Дадоенкова ${ }^{1,3}$, Ф.Ф.Л. Бентивенья ${ }^{3}$ \\ ${ }^{1}$ Ульяновский государственный университет, Ульяновск, Россия \\ ${ }^{2}$ Институт нанотехнологий микроэлектроники РАН, Москва, Россия \\ ${ }^{3}$ Ульяновский филиал Института радиотехники и электроники им. В.А. Котельникова РАН, \\ Ульяновск, Россия \\ ${ }^{4}$ Lab-STICC, ENIB, Brest, France \\ *E-mail: $\underline{\text { moiseev@ulsu.ru }}$
}

DOI: 10.31868/RFL2020.213-214

В настоящей работе предложена модель наноразмерного генератора поверхностных плазмон-поляритонов (ППП) на основе одностенной углеродной нанотрубки (УНТ), в которой реализован механизм усиления посредством прямой передачи энергии от постоянного электрического тока накачки, протекающего по УНТ, к электромагнитной волне (волне ППП). Подобный принцип хорошо известен в СВЧ технике (лампа бегущей волны и др.) [1]. Эффективность взаимодействия тока и плазмонной волны высока при выполнении условия фазового синхронизма, то есть когда фазовая скорость ППП волны и дрейфовая скорость носителей заряда примерно одинаковы. Основные положения предлагаемой схемы усиления ППП в изолированной УНТ, находящейся в воздухе (вакууме) вдали от границ раздела сред, изложены в нашей работе [2]. В настоящей работе определены условия усиления в более реалистичных условиях - при наличии подстилающей среды. Обратная положительная связь в УНТ реализуется за счет рассеяния усиленной ППП волны на периодическом потенциале, связанным с пространственной модуляцией диэлектрической проницаемости подложки.

Наличие подложки оказывает существенное влияние на эффективный показатель преломления ППП в УНИ. На рис. 1(а) представлены дисперсионные зависимости ППП в одностенной УНТ для различных значений показателя преломления подстилающей среды (поглощением в подстилающей среде пренебрегается). Видно, что постоянная распространения и коэффициент поглощения возрастают с увеличением частоты ППП и показателя преломления подложки. На рис. 1(b) показано распределение поля вблизи УНТ на подложке при различных значениях показателя преломления последней. Можно видеть, что с увеличением показателя преломления степень локализации поля увеличивается со смещением максимума к поверхности подложки. Эти свойства ППП позволяют контролировать эффективный показатель преломления ППП в УНТ путем модулирования оптических свойств подложки.

Расчеты показывают, что согласование дрейфовой скорости носителей тока накачки (около $10^{6} \mathrm{M} / \mathrm{c}$ [3]) и фазовой скорости ППП упрощается в структуре с подстилающей средой, имеющей более высокий показатель преломления. Для кремниевой подложки условие усиления ППП за счет энергии носителей тока накачки реализуется в полосе частот вблизи частоты $2.4 \times 10^{14} \mathrm{c}^{-1}$. На частоте 3.5 $\times 10^{14} \mathrm{c}^{-1}$ эффективный коэффициент усиления ППП (превышение усиления над материальными потерями) достигает значения $2 \times 10^{8} \mathrm{M}^{-1}$, что значительно превышает величину коэффициента потерь $0.6 \times 10^{8} \mathrm{M}^{-1}$. 


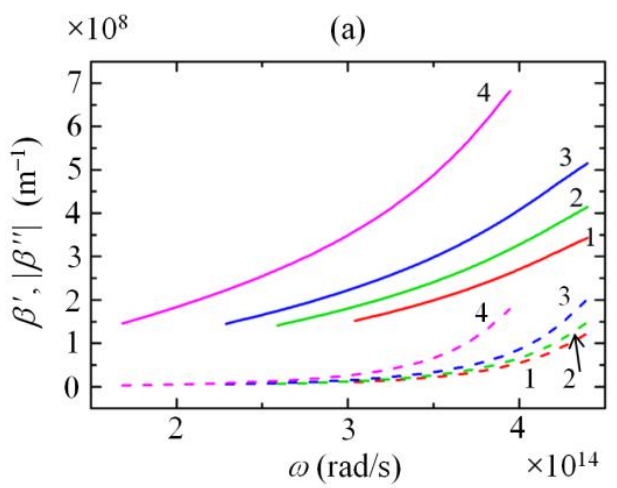

(b)

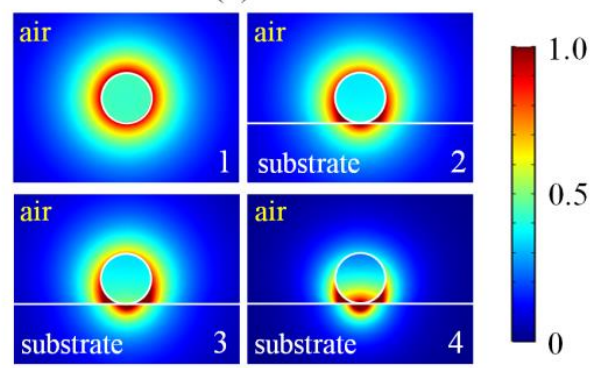

Рис. 1. (а) Частотная зависимость постоянной распространения $\beta^{\prime}$ (сплошные линии) и коэффициента материальных потерь $\left|\beta^{\prime \prime}\right|$ (пунктирные линии) ППП в УНТ на подложке с показателем преломления: (1) $n=1$ (воздух), (2) $n=1.46$ (SiO2), (3) $n=1.99 \quad\left(\mathrm{Si}_{3} \mathrm{~N}_{4}\right), \quad$ (4) $n=3.4 \quad(\mathrm{Si}) . \quad$ (b) Распределение модуля напряжённости электрического поля вблизи УНТ на частоте $3.7 \times 10^{14} \mathrm{c}^{-1}$. Параметры УНТ: диаметр 10 нм, концентрация свободных носителей заряда $10^{12} \mathrm{~cm}^{-1}$.

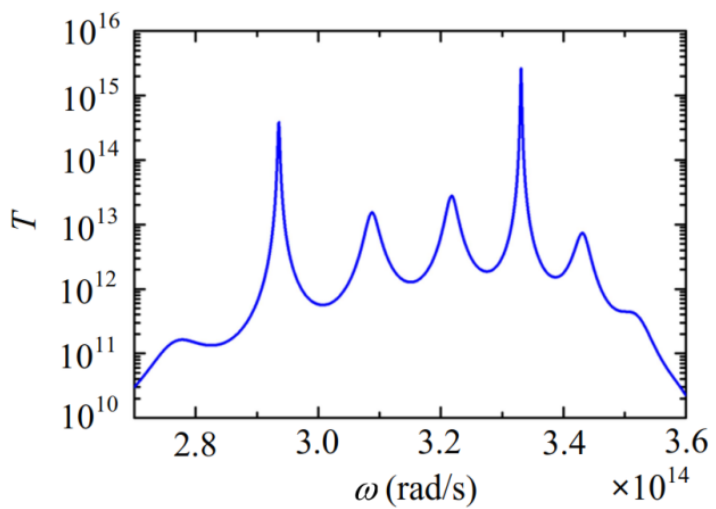

Рис. 2. Частотная зависимость коэффициента пропускания УНТ для периода модуляции показателя преломления подложки 10 нм на длине 100 нм.

В приближении неистощимой токовой накачки динамика распространения прямой и обратной ППП волн в УНТ с периодическим потенциалом описывается системой уравнений для лазеров с распределенной обратной связью [4], записанной с учетом усиления ППП в направлении дрейфа носителей тока накачки. Расчетные значения коэффициента пропускания УНТ представлены на рис. 2. Наиболее интенсивные плазмонные моды наблюдаются вблизи частот $2.92 \cdot 10^{14} \mathrm{c}^{-1}$ и $3.32 \cdot 10^{14} \mathrm{c}^{-1}$. Высокие значения коэффициента усиления $\left(\sim 10^{8} \mathrm{~m}^{-1}\right)$ обеспечивают резонансное усиление ППП даже при небольшой амплитуде модуляции показателя преломления подстилающей среды.

Работа выполнена при финансовой поддержке Министерства образования и науки РФ (проекты 0004-2019-0002, 0830-2020-0009, 075-00629-19-00), Российского фонда фундаментальных исследований (проекты 18-29-19101, 19-42-730010).

\section{Литература}

[1] Д.И. Трубецков, А.Е. Храмов. Лекиии по СВЧ электронике для физиков. Том 1. (М: Физматлит, 2003)

[2] A.S. Kadochkin, S. G. Moiseev et al, Optics Express 25, 27165-27171 (2017)

[3] K. Liu, J. Deslippe et al, Nat. Nanotechnol. 7 325-329 (2012)

[4] A. Yariv, P. Yeh, Optical Waves in Crystals (Wiley: New York, 1984) 